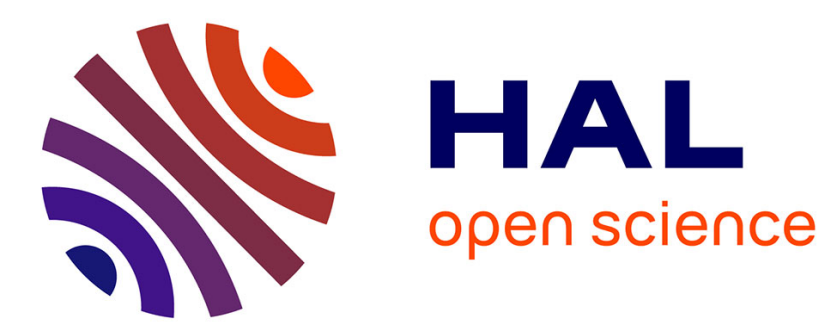

\title{
Distance Education Standards and Legal Issues - Computing Education Perspective
}

Larissa Vladinova, Alexander Mintchev, Krassen Stefanov

\section{To cite this version:}

Larissa Vladinova, Alexander Mintchev, Krassen Stefanov. Distance Education Standards and Legal Issues - Computing Education Perspective. CompSysTech'2003 International conference, 2003, Bulgaria. 6 p. hal-00190354

\section{HAL Id: hal-00190354 https://telearn.archives-ouvertes.fr/hal-00190354}

Submitted on 23 Nov 2007

HAL is a multi-disciplinary open access archive for the deposit and dissemination of scientific research documents, whether they are published or not. The documents may come from teaching and research institutions in France or abroad, or from public or private research centers.
L'archive ouverte pluridisciplinaire HAL, est destinée au dépôt et à la diffusion de documents scientifiques de niveau recherche, publiés ou non, émanant des établissements d'enseignement et de recherche français ou étrangers, des laboratoires publics ou privés. 


\title{
Distance Education Standards and Legal Issues - Computing Education Perspective
}

\author{
Larisa Vladinova, Alexander Minchev, Krassen Stefanov
}

\begin{abstract}
This paper aims to examine the legal issues related to the recognition of professional ICT qualifications amongst countries in EU, as well as international and European standards for education and training, certification and validation of distance training courses, etc. At the end we are proposing a course structure, certificate format, as well as the educational standards to be followed in the design process.
\end{abstract}

Key words: Distance Learning, e-Learning, Standards, Diploma Recognition, Course Structure

\section{INTRODUCTION}

The main objective of the 5 FP IST DIOGENE project is to design, implement and evaluate training environment for ICT individual training. It has to be able to support learners during the whole cycle of the training, from the definition of objectives to the assessment of results through the construction of custom self-adaptive courses. The designed instruction will be available for ICT professionals from different countries through web-based learning portals.

In this paper we investigate existing specifications in E-Learning and Distance education, stressing on the ICT professional education, as well as all legal issues surrounding this education - recognition of diplomas, certificates, quality issues, etc.

At the end we give the solutions chosen in the DIOGENE project, providing them with the necessary argumentation.

\section{DISTANCE LEARNING AND e-LEARNING}

"Distance learning" covers any form of study not under continuous or immediate supervision (an autonomous component invariably supported by tutoring and counselling systems which ideally are provided at regional/local study centres and to an increasing extent by modern communications media).

Flexible learning is enabling learners to learn when they want (frequency, timing, duration), how they want (modes of learning), and what they want (that is learners can define what constitutes learning to them)."

The definition of E-Learning adopted by Cedefop [1] is a rather broad one, namely:

'Learning that is supported by information and communication technologies (ICT). Elearning is, therefore, not limited to 'digital literacy' (the acquisition of IT competence) but may encompass multiple formats and hybrid methodologies, in particular, the use of software, Internet, CD-ROM, online learning or any other electronic or interactive media.'

\section{SPECIFICATIONS ON A WEB-BASED COURSE STRUCTURE}

\section{e-Learning in Universities}

On September, 17-18 , 2001 in Brussels a seminar on the topic "EU Policies and Strategic Change for eLearning in Universities" was held with the participation of rectors, 
vice-rectors and specialists in the filed of Information and Communication Technologies (ICTs) from almost all EU Member States. This seminar ended with the following conclusions:

- It was suggested that in accrediting Universities within EU, the extent to which they use ICTs in their educational and scientific activity shall be evaluated on the first place.

- A numerical criterion for determining the extent to which ICTs are used in the activity of a University was formulated - the number of Web-based courses offered, i.e. the subjects, for which web-sites exist.

- General requirements on the web-based courses offered by a University were specified. According to these requirements, a web-based course must contain:

o Annotation of the subject matter;

o Course syllabus;

o Recommended Bibliography;

o Lecture Notes;

o Seminars;

o Assignments and test for self-control and control by a mentor;

o Exam synopsis;

o Information on the team of course lecturer(s), course assistant(s), course instructor(s);

o Classes schedule;

o Current announcements

- The concept of "Virtual Laboratory" was defined as a set of web-based programming models of real devices and systems, with which students work with in order to improve their theoretic knowledge and practical skills".

- A criterion was formulated for the readiness of a university to turn into a virtual one - web-sites must be established for all general subjects, which comply with the above requirements, and virtual laboratories must be set up for all the general subjects.

\section{ACM Computing Curricula}

The Association for Computing Machinery and the Computer Society of the IEEE created a Computing Curricula [3], which contains curricular recommendations for baccalaureate programs in the discipline of computing. According to ACM/IEEE-CS report the term "computing" includes "computer science," "computer engineering", "computer science and engineering," and other similar areas. Together with the classifications of subareas of the discipline computing the report proposes components of a course description and the structure of presentation of a knowledge unit. Knowledge units are smaller packages of closely related topics. They could be combined into courses in different ways according to particular needs and priorities of different institutions.

Instructional Hierarchy of CBT Terms by Aviation Industry CBT Committee (AICC)

The AICC was set up in 1988. It develops guidelines for aviation industry in development, delivery, and evaluation of Computer- Based Training (CBT) and related training 
technologies. The document "Hierarchy of CBT Terms for AICC Publications" [2] provides definitions and describes the hierarchical relationships of terms, related to courseware. The instructional terms are organised in ten levels. The labels for each level in the hierarchy used by the AICC are shown in this table:

Table 1. Ten Levels of Instructional Terms according to AICC

\begin{tabular}{|c|c|}
\hline Name & Level \\
\hline Curriculum & 1 \\
\hline Course & 2 \\
\hline Chapter & 3 \\
\hline Subchapter & 4 \\
\hline Module & 5 \\
\hline Lesson & 6 \\
\hline Assignable unit & 6 \\
\hline Topic & 7 \\
\hline Sequence & 8 \\
\hline Frame & 9 \\
\hline Screen & 9 \\
\hline Object & 10 \\
\hline
\end{tabular}

\section{EUROPEAN REGULATION ON THE MUTUAL RECOGNITION OF DIPLOMAS AND CERTIFICATES}

One of the major obstacles for people that want to work or learn in another EU country is that their qualifications may not be recognised abroad. To tackle these obstacles, the EU has introduced several instruments, aiming at facilitating transparency and recognition of qualifications for academic, vocational and professional titles.

Instruments facilitating academic and vocational qualification recognition

To facilitate the recognition of non-regulated vocational qualifications, the Commission and the Member States have developed a number of tools supporting transfer and transparency of qualifications:

- ECTS, the European Credit Transfer System for recognising students' study periods abroad

- Diploma Supplement, which includes both a graduate's personal achievements and a description of his or her national higher education system

- Certificate Supplement, been developed for vocational qualifications and is currently being tested in the Member States

- The European curriculum vitae gives a comprehensive standardised overview of education attainments and work experience of an individual. It is complementary to the certificate supplement.

- The "European pathway for training" and the "EUROPASS Training" are the two interrelated core concepts of the Council decision on the promotion of 
European pathways for work-linked training, including apprenticeship (1999/51/EC, published in OJ L 17 of 22.1.1999), adopted on 21 December 1998.

\section{PROFESSIONAL ASSOCIATIONS IN COMPUTING EDUCATION}

The Institute of IT Training

The Institute of IT Training is the world's first professional body for IT training professionals. Launched in 1995, the Institute has made significant progress in developing and promoting high standards of excellence within the profession. The Institute of IT Training is a not for profit organisation and is governed by a Board of officials that has statutory responsibility for running the Institute's affairs. Individual membership continues to grow rapidly as trainers perceive tangible benefits from being identified with their professional body. The institute is located in Coventry, United Kingdom.

The Institute of IT Training publishes standards, which encompass all aspects of IT training, development, and delivery. The most relevant of them fall into the scope of the "Accreditation programme and code of practice for e-Learning providers".

The Institute's Standards address the organisation (ie: the provider), learning materials (ie: the products) and developer (ie: the individual practitioner) levels, and define current best practice in these areas. The Standards, reviewed on an annual basis to ensure continued currency and applicability, comprise:

o Code of practice for e-Learning providers

o e-Learning provider accreditation programme

o Standards for e-Learning materials

o Competencies for developers of e-Learning materials

\section{The International Association of Information Technology Trainers (ITrain)}

ITrain is a non-profit association of 6,781 information technology (IT) professionals located in 166 countries and provides members with access to resources and support services related to IT training.. Membership in ITrain facilitates trainers and their staff by giving them access to resources and support services that aren't available anywhere else. Members of ITrain could be:

1. Organization - Training organizations and departments, including educational institutions. Membership extends to all collocated trainers.

2. Individual - Trainers in private practice.

3. Vendor - Providers of products and services of value to trainers.

Certification programs are available to trainers, training centers, and publishers of training materials. Professional Technical Trainer (PTT) certification is available to all members. Training organizations may apply to have their entire program recognized through the Professional Training Center (PTC) certification. Curriculum developers may pursue Professional Training Materials (PTM) certification for each of their products.

\section{The Association of Internet Professionals}

The Association of Internet Professionals (AIP) is founded through the alliance of the Internet Developers Association (IDA) and the International Society of Internet Professionals (ISIP) in 1997 in USA, AIP represents more than 250,000 individual Internet 
professionals, and over 250 leading Internet industry companies and educational institutions. In 2000 the AIP acquired the International Interactive Computer Society (IICS) making AIP the largest non-profit association in the Internet Industry. The AIP Certification Accreditation Council, an arm of AIP [4], sets standards and accredits various Internet training and certification programs. While it does not create curricula or tests, it does study the curricula and tests of training companies and educational institutions for adherence to a common set of standards. The decision-making board includes leaders in academia, IT staffing, and the software and hardware industries.

\section{CONCLUSIONS: WHAT WE IMPLENEMTED IN DIOGENE}

What we are interested to implement in DIOGENE from the survey we made is the "stuff" itself provided by DIOGENE-courses, learning materials- their structure and content; the process of teaching and following a course respectively; what kind/type of certificate does a learner attending a course finally get after having successfully completing it? Shall the organization running DIOEGENE, including tutors and instructors be recognized /certified as IT Trainer provider or e-learning provider and by whom, etc.?

Regarding structure and content of any course, delivered by Diogene, we adopted the scheme below, which is based upon General requirements on the web-based courses established on the seminar "EU Policies and Strategic Change for eLearning in Universities" in Brussels, the Instructional Hierarchy of CBT Terms by Aviation Industry CBT Committee (AICC) and Components of a course description offered by ACM Computing Currcula.

In this scheme, any element embraced with [] is optional, and elements are related in a hierarchical structure.

\section{- [Course Number] Course Title}

- $\quad$ Annotation of the course- short subject matter description, highlighting major topics and expected outcomes;

- $\quad$ Course Lecturers information on course lecturers, facilitators, etc.

- $\quad$ Recommended Bibliography-paper based, web-based materials;

- [Prerequisites for taking part in the course] - required courses taken or background;

- $\quad$ Course schedule - syllabus + time scheduling;

- $\quad$ Lecture Notes- using AICC instructional hierarchy levels:

Chapter

-Subchapters

-Module

-Lesson/ unit to assign;

-Topic;

-Sequence

-Frame/screen

-Object (Learning Object)

- Assignments and tests

- Communication Tools] 
Regarding the certificate issued after accomplishing a course offered by Diogene, we decided that it be supplemented by a certificate supplement. A certificate supplement is issued by the awarding authorities and provides information mainly on:

o The skills and competences acquired;

o The range of occupations accessible;

o The awarding and accreditation bodies;

o The level of the certificate;

o The different ways of acquiring the certificate;

o The entry requirements and access opportunities to next level education.

Regarding standards and specification adopted by professional organisations, the most appropriate for DIOGENE environment to adhere to are Codes of practices of the Institute of IT Training, Coventry, UK, because of the following reasons:

- They contain practical advice for IT training providers and developers for learning materials;

- They offer well-structured Standards for e-learning materials, programs for certification and attestation.

- IT Training an European organisation, which means that its common values, established practices and professional standards are consistent with European norms and standards.

This implies that any certificate, accreditation, evaluation, etc. issued by this organisation would be more relevant to the European dimension of DIOGENE than those issued by the other two professional associations.

\section{REFERENCES}

[1] European Centre for the Development of Vocational Training http://www.cedefop.eu.int/

[2] Hierarchy of CBT Terms for AICC Publications

http://www.aicc.org/docs/tech/crs003.rtf

[3] Report of the ACM/IEEE-CS Joint Curriculum Task Force http://www.acm.org

[4] The Association of Internet Professionals - Certification Accreditation Council http://acac.association.org/

\section{ABOUT THE AUTHORS}

Larissa Vladinova PhD Student, Department of Information technologies, Sofia University Phone: +359 865-61-57, E-mail: lary@fmi.uni-sofia.bg

Alexander Mintchev, PhD Student, Department of Information technologies, Sofia University Phone: +359 865-61-57, E-mail: alexanderdm@fmi.uni-sofia.bg

Assoc.Prof. Dr. Krassen Stefanov, Department of Information technologies, Sofia University, Phone: +359 865-61-57, E-mail: krassen@fmi.uni-sofia.bg 